\title{
Adipose Tissue as an Endocrine Organ: An Update on Pro-inflammatory and Anti-inflammatory Microenvironment
}

\section{Kvido Smitka, Dana Marešová}

Institute of Physiology, First Faculty of Medicine, Charles University in Prague, Prague, Czech Republic

Received December 12, 2014; Accepted June 1, 2015.

Key words: Leptin - Adiponectin - Adipolin - Visfatin - Omentin - PEDF Progranulin - Resistin

Abstract: Adipose tissue is recognized as an active endocrine organ that produces a number of endocrine substances referred to as "adipokines" including leptin, adiponectin, adipolin, visfatin, omentin, tumour necrosis factor-alpha (TNF- $\alpha$ ), interleukin-6 (IL-6), resistin, pigment epithelium-derived factor (PEDF), and progranulin (PGRN) which play an important role in the food intake regulation and significantly influence insulin sensitivity and in some cases directly affect insulin resistance in skeletal muscle, liver, and adipose tissue. The review summarizes current knowledge about adipose tissue-derived hormones and their influence on energy homeostasis regulation. The possible therapeutic potential of these adipokines in the treatment of insulin resistance, endothelial dysfunction, a pro-inflammatory response, obesity, eating disorders, progression of atherosclerosis, type 1 diabetes, and type 2 diabetes is discussed.

This study was supported by grant by PRVOUK-P34/LF1/7.

Mailing Address: Assoc. Prof. Dana Marešová, MD., PhD., Institute of Physiology, First Faculty of Medicine, Charles University in Prague, Albertov 5, 12800 Prague 2, Czech Republic; Phone: +420 224968 410; e-mail: dana.maresova@If1.cuni.cz 


\section{Introduction}

Adipose tissue (AT) was originally considered as a passive reservoir for energy storage, mechanical and heat insulation, and participating in the regulation of thermogenesis (Trayhurn and Beattie, 2001). However, AT is now known to synthesize and secrete a variety of bioactive peptides, currently known as "adipokines", which act at both autocrine/paracrine and endocrine level (Proença et al., 2014). Adipokines participate in the regulation of glucose and lipid metabolism, energy homeostasis, feeding behaviour, insulin sensitivity, inflammation, immunity, adipogenesis, vascular function or coagulation (Romacho et al., 2014) (Figure 1). AT is innervated by the sympathetic nerve endings and the cross-talk between adipocytes and hypothalamic neurons as well with sympathetic nervous system neurons is mediated by multiple signals and may control adipokine secretion. Furthermore, AT is composed not only of differentiated mature adipocytes but also of other cell types termed the stroma-vascular fraction (SVF), containing endothelial cells, nerve cells, immunocompetent cells especially monocytes/macrophages, $T$ and B lymphocytes, dendritic cells, mast cells, neutrophils, eosinophils, pericytes, fibroblasts, myocytes, adipose-derived stem cells or undifferentiated adipose precursor cells (3T3-L1 preadipocytes) (Wozniak et al., 2009; Esteve Ràfols, 2014; Exley et al., 2014;Vieira-Potter, 2014). The balance between these different cell types is closely related to maintenance of energy homeostasis. An adipocyte size, number and polarization of lymphocytes and infiltrated monocytes/macrophages are closely related to metabolic and obesityrelated diseases (Vieira-Potter, 2014).

AT is the largest endocrine organ by secreting hundreds of hormones and cytokines. These adipokines affect processes in the peripheral and the central nervous system. In this vein, TNF- $\alpha$ and macrophages are associated with peripheral diabetic neuropathy contributing to the diabetic microvascular complications (Purwata, 2011). Moreover, it is known that adipokines regulate not only feeding behaviour, but also neurodegeneration, synaptic plasticity, neurogenesis, axon growth, apoptotic cell death, cognitive deficits, memory consolidation, and learning processes (Arnoldussen et al., 2014).

Therefore, AT produces a variety of pro-inflammatory and anti-inflammatory hormones including adipokines leptin, resistin, adiponectin, adipolin, visfatin, and omentin as well as cytokines such as tumour necrosis factor-alpha (TNF- $\alpha$ ), interleukin-6 (IL-6), pigment epithelium-derived factor (PEDF), and progranulin (PGRN). Pro-inflammatory hormones produced by AT have been implicated as participants in the development of insulin resistance and obesity and the increased risk of cardiovascular disease, whereas anti-inflammatory and insulin-sensitizing adipokines adiponectin, adipolin, and omentin are decreased (de Souza Batista et al., 2007; Knights et al., 2014; Proença et al., 2014; Romacho et al., 2014). Also, PEDF and PGRN are novel substances affecting insulin sensitivity (Famulla et al., 2011; Li et al., 2014). Furthermore, pro- and anti-inflammatory factors are also 


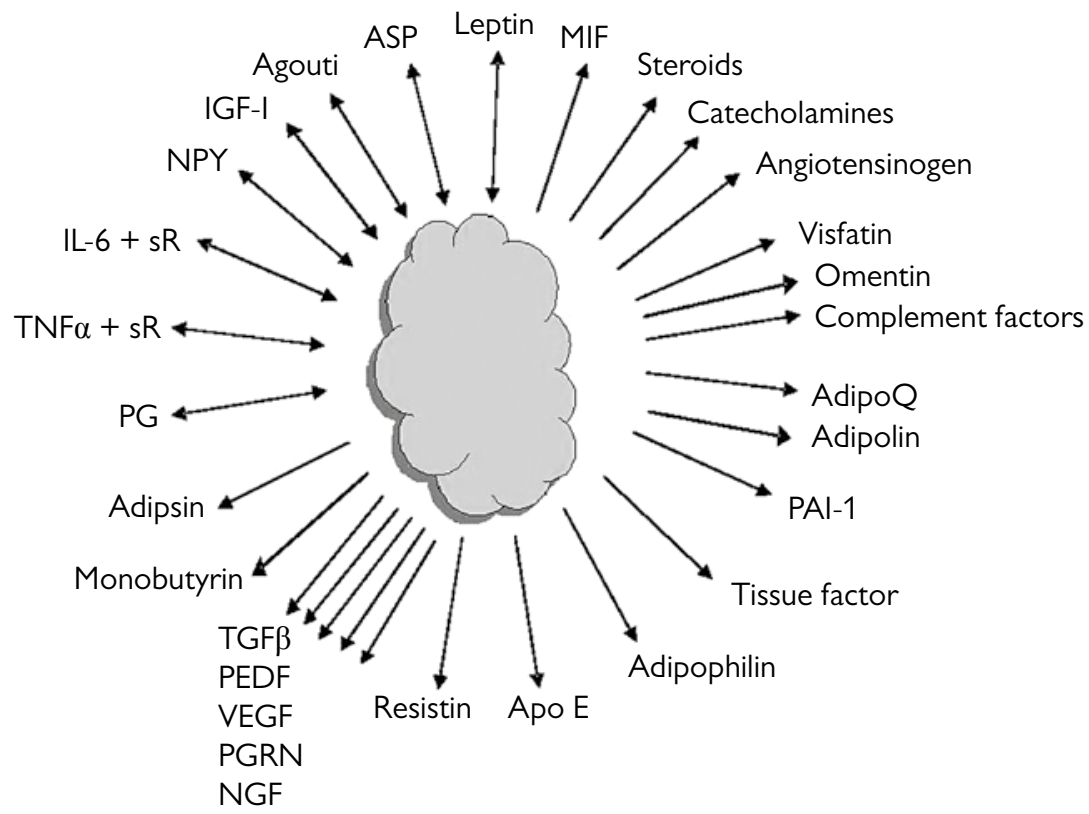

Figure 1 -Adipose tissue is a network of endocrine signals that regulates glucose and lipid metabolism, energy homeostasis, pro- and anti-inflammatory response and enables the organism to adapt to a range of different metabolic challenges such as starvation, stress, infection, and periods of energy excess.

AdipoQ, Adiponectin, Adipocyte complement-related protein of $30 \mathrm{kDa}$ (regulates glucose, lipid homeostasis, and insulin sensitivity), Adipolin (is an insulin-sensitizing adipose tissue-derived hormone), Visfatin (is an important adipokine that involved in glucose and lipid metabolism and is related to the pathogenesis of insulin resistance), Omentin (is a novel depot-specific adipokine with insulin-sensitizing and anti-inflammatory properties), TGF- $\beta$, transforming growth factor-beta (regulates a wide variety of biological response including proliferation, differentiation, and apoptosis), PEDF, pigment epithelium-derived factor (plays a causal role in insulin resistance), VEGF, vascular endothelial growth factor (regulator of angiogenesis), PGRN, progranulin (is associated with systemic insulin resistance, metabolic syndrome, and obesity), NGF, nerve growth factor (is secreted by white adipocytes and involved in an inflammatory response), Adipophilin (may be a specific marker for lipid accumulation in the cells), Apo E, apolipoprotein E (important regulator of lipoprotein metabolism), IGF-I, insulin growth factor I (stimulates proliferation of a wide variety of cells and mediates many of the effects of growth hormone), ASP, acylation stimulating protein (influences the rate of triacylglycerol synthesis in adipose tissue), Agouti-related protein, AGRP (regulates adipose tissue function), NPY, Neuropeptide Y (orexigenic NPY is also produced by adipocytes and mediates reduction of leptin for central feedback of adiposity signals), PG, prostaglandin (implicates in regulatory functions such as inflammation and blood clotting), Catecholamines (are synthesized in adipose tissue), Angiotensinogen (precursor of angiotensin II, regulator of blood pressure and electrolyte homeostasis), Leptin (signals to the brain about body fat stores, regulation of appetite and energy expenditure), MIF, macrophage migration inhibitory factor (involved in pro-inflammatory process and immunoregulation), Adipsin (possible link between the activation of the alternative complement pathway and adipose tissue metabolism), Monobutyrin, 1-butyryl-glycerol (is a vasoactive factor secreted by differentiating adipocytes), IL-6 + sR - interleukin-6 and soluble receptors (implicated in host defense and in glucose and lipid metabolism), $T N F \alpha+s R-$ tumour necrosis factor alpha and soluble receptors (interferes with insulin receptor, development of insulin resistance in obesity), PAl-1, plasminogen activator inhibitor-1 (inhibitor of fibrinolytic system), Tissue factor (cellular initiator of the coagulation cascade), Resistin (hormonal factor relates with the resistance to insulin in obesity). 
produced by activated macrophages. M1 or "classically activated" macrophages are characterized by increased production of TNF- $\alpha$ and IL-6, which promote insulin resistance and state of low-grade inflammation in adipocyte hypertrophy in obese patients. However, M2 or "alternatively activated" macrophages are characterized by increased production of anti-inflammatory cytokine interleukin-10 (IL-10) in lean AT and adipocytes are smaller in size and tend to be more sensitive (Galic et al., 2010). Obesity causes a shift of macrophage subtypes in AT from M2 to M1 activation leading to higher levels of pro-inflammatory adipokines which induce insulin resistance (Lumeng et al., 2007).

Visceral AT is morphologically and functionally different from subcutaneous AT. Visceral and subcutaneous AT exhibit unique adipokine expression and secretion profiles (Kershaw and Flier, 2004). Visceral AT produces more pro-inflammatory cytokines such as IL-6, plasminogen activator inhibitor (PAI-1) and angiotensinogen, whereas subcutaneous AT secretes more leptin and larger quantities of antiinflammatory and insulin-sensitizing adiponectin. Furthermore, visceral AT is composed of large insulin-resistant adipocytes and has a well-developed vasculature, rich in blood supply, heavily innervated and more sensitive to lipolysis, with the infiltration of higher levels of macrophages, $T$ cells, and natural killer cells. Thus, pro-inflammatory cytokines and metabolites from visceral AT and AT macrophages are released into portal vein and directly impact liver metabolism. Indeed, visceral AT accumulation has been linked to increased risk of obesityrelated diseases and mortality. On the contrary, subcutaneous AT is characterised by small insulin-sensitive adipocytes with less vascularity, innervation, and cellular infiltration, and serves as storage of fat depot, which is drained systematically (Ibrahim, 2010). Increased subcutaneous AT is associated with a reduced risk of obesity-induced metabolic dysregulation and enhanced insulin sensitivity, and thus, subcutaneous AT accumulation particularly in the thighs and buttocks is proposed to be protective when compared with the deleterious consequences of visceral adiposity (Booth et al., 2014).

The aim of this review was to describe the role of selected and recently discovered adipokines with a focus on their source and their effects on wholebody energy metabolism and insulin resistance.

\section{An overview of adipose tissue-derived hormones}

\section{Leptin}

Leptin is a $16 \mathrm{kDa}$ protein hormone produced primarily by adipocytes (Zhang et al., 1994) that regulates food intake and energy expenditure. Leptin was first identified as the product of the ob gene in obese ob/ob mice (Zhang et al., 1994). Leptin deficient ob/ob mice are hyperphagic and morbidly obese, indicating increased energy intake with reduced energy expenditure. Indeed, leptin administration in congenitally deficient ob/ob mice causes a decrease in 
appetite and promotes weight loss (Campfield et al., 1995). In humans, congenital leptin deficiency is associated with severe obesity, glucose intolerance, and insulin resistance which can be reversed by leptin replacement therapy (Farooqi et al., 1999). Thus, in congenitally leptin deficient children and adults, recombinant human leptin therapy successfully reduces obesity and restores reproductive functioning, and improves the hypothalamic dysfunctions associated with leptin deficiency (Farooqi et al., 2002; Licinio et al., 2004). Therefore, it was documented that the treatment with recombinant human leptin is useful in monogenic human obesity caused by leptin deficiency (Farooqi and O'Rahilly, 2005; Dubern and Clement, 2012).

Currently it is demonstrated that leptin levels are positively correlated with body fat in obese individuals and decreased in lean subjects (Mendoza-Núñez et al., 2002). In fact, leptin is an important regulator of energy homeostasis to inform the hypothalamic satiety centre of the body fat stores (Nogueiras et al., 2008). Therefore, leptin functions as an afferent signal in a negative feedback loop that regulates food intake to maintain homeostatic control of AT mass (Friedman, 2014). Indeed, leptin serves as an "adipostat", as circulating plasma leptin levels reflect the degree of adiposity and its release from adipocytes signals to the brain to trigger the suppression of food intake and to boost energy expenditure. Moreover, it was documented that leptin is the major hormone to trigger the adaptation of an organism to food restriction (Ahima et al., 1996). Hypoleptinaemia is actually accompanied by a decrease in basal energy expenditure in women with amenorrhea. Indeed, in anorexia nervosa (AN) and bulimia nervosa (BN) patients, plasma leptin levels were found to be lower than in normal weight controls (Nedvídková et al., 2000; Dostálová et al., 2007; Smitka et al., 2011, 2013a, b). However, realimentation leads to an increase in plasma leptin levels in $A N$ and $B N$ patients.

Adipose-derived leptin accelerates puberty in human and animal studies and restores reproductive function in leptin-deficient mice and humans (Hileman et al., 2000). Plasma leptin levels are decreased in healthy men when compared with healthy women. It was shown that leptin replacement during fasting prevents starvation-induced changes in the hypothalamic-pituitary-gonadal axis in healthy men (Chan et al., 2003). Moreover, administration of recombinant leptin resulted in recuperation of reproductive outcomes and corrected in the gonadal, thyroid, growth hormone $(\mathrm{GH})$, and adrenal axes in lean women with hypothalamic amenorrhea (Welt et al., 2004).

Leptin exerts insulin-like effects on glucose metabolism and was considered as potential treatment to decrease hyperglycaemia in type 1 diabetes in mice (Wang et al., 2010). Furthermore, leptin improves insulin sensitivity in mice through activation of adenosine monophosphate-activated protein kinase (AMPK) contributing to an increased oxidation of free fatty acids (FFA), thereby reducing ectopic accumulation of lipids in skeletal muscle and liver (Minokoshi et al., 
2002). Importantly, treatment with leptin and adiponectin together completely reversed insulin resistance in lipoatrophic mice when compared with only partial improvement with adiponectin or leptin alone (Yamauchi et al., 2001).

Leptin exerts its effect on central and peripheral tissues by binding to its receptor (Ob-R). This Ob-R was found primarily in the dorsomedial and ventromedial hypothalamic nuclei involved in the control of food intake. This receptor was also found in several peripheral tissues including AT, skeletal muscle, liver, pancreatic beta cells, blood mononuclear cells, lymphocytes, and endothelial cells. Thus, leptin acts on immune and endothelial cells to stimulate the production of a spectrum of pro-inflammatory cytokines (Cao, 2014). Indeed, an increased pro-inflammatory response has been reported in hyperleptinaemia with leptin resistance during obesity (Vázquez-Vela et al., 2008) leading to hepatic steatosis and ectopic accumulation of lipids in skeletal muscle, heart, and pancreas.

In obese humans, endogenous high leptin levels or exogenous leptin treatment was ineffective in terms of weight loss (Zelissen et al., 2005), consistent with the concept of leptin resistance (Bjørbaek and Kahn, 2004; Sáinz et al., 2015). The potential mechanisms for leptin resistance has been proposed and include defective transport of leptin across the blood-brain barrier (Bjørbaek and Kahn, 2004; Flier, 2004), defects in leptin receptor/post-receptor signalling cascade through molecular mediators of leptin resistance such as suppressor of cytokine signalling-3 (SOCS3) (Bjørbaek et al., 1998) and protein tyrosine phosphatase 1B (PTP1B) (Cheng et al., 2002), and a desensitization of cellular downstream signalling at central and peripheral level (Münzberg and Myers, 2005). Finally, in this context, leptin desensitization found in obese humans can affect the regulation of lipid and glucose handling in the AT, muscle, and liver as well as the gastrointestinal nutrient utilization and contribute to the worsening of the obese state (Sáinz et al., 2015).

As the above mentioned, leptin-deficient mice and humans exhibit severe hyperphagia and obesity, and administration of recombinant leptin leads to an almost complete reversal of this phenotype (Campfield et al., 1995; Farooqi et al., 1999, 2002; Licinio et al., 2004; Farooqi and O'Rahilly, 2005; Dubern and Clement, 2012). However, in non-leptin-deficient human obesity, administration of recombinant human leptin has failed to produce meaningful weight loss in obese men and women with glucose intolerance and type 2 diabetes, presumably due to leptin resistance that impairs leptin action (Heymsfield et al., 1999; Hukshorn et al., 2000, 2002; Moon et al., 2013).

It was documented that leptin exerts insulin-like effects on glucose metabolism and that leptin is considered as potential treatment to attenuate hyperglycaemia in type 1 diabetes in mice, rats, and lipodystrophy syndromes in humans (Petersen et al., 2002; Wang et al., 2010; Perry et al., 2014). In fact, leptin has been identified as a suppressor of ACTH-dependent cortisol secretion in vitro (Szücs et al., 2001). Thus, Perry et al. (2014) showed that administration of leptin corrected fasting hyperglycaemia and ketoacidosis in rodent models of type 1 diabetes through 
glucocorticoid-mediated decreases in lipolysis. Likewise, Hathout et al. (1999) observed that plasma leptin increase was paralleled by a rise in insulin levels and a decline in blood glucose and cortisol levels after insulin treatment in patients with type 1 diabetes. These results have potential translational significance for leptin replacement, i.e. that plasma cortisol levels were increased before insulin treatment in patients with type 1 diabetes and in patients with diabetic ketoacidosis (Hathout et al., 1999; Kitabchi and Umpierrez, 2003; Kratzsch et al., 2006). Indeed, Oral (2012) summarized the basic and clinical data that provide support to exploration of administration of recombinant leptin as an adjunctive therapy for patients suffering from type 1 diabetes. For example, leptin replacement can reduce the number of insulin injections as well as the total daily insulin dose required for patients with type 1 diabetes (Oral, 2012). Moreover, leptin replacement can suppress glucagon levels and hyperglucagonaemia is a hallmark feature of type 1 diabetes (Oral, 2012). Nevertheless, the role of leptin as an insulin-sensitizing adipokine still needs further clarification (Knights et al., 2014).

\section{Adiponectin}

Adiponectin is a protein produced by adipocytes, which was discovered in the 1990 s by four independent groups, and it was named adipocyte complementrelated protein of $30 \mathrm{kDa}$, Acrp30, AdipoQ, apM1, and GBP28 (Scherer et al., 1995; Hu et al., 1996; Maeda et al., 1996; Nakano et al., 1996). It was believed that adiponectin was secreted predominantly by AT. However, adiponectin is also produced by human cardiomyocytes and human skeletal muscle (BrochuGaudreau et al., 2010). Adiponectin plasma levels are negatively correlated with body mass index (BMI) and fat mass in patients with obesity, type 2 diabetes, and cardiovascular disease (Weyer et al., 2001). Unlike leptin, adiponectin plasma levels are elevated in lean human subjects and reduced in human and animal subjects with obesity and type 2 diabetes (Hotta et al., 2000, 2001; Yang et al., 2001).

Adiponectin exists as a full-length protein of $30 \mathrm{kDa}$ and was found in the circulation as a number of multimeric complexes, i.e. low molecular weight (LMW) trimers, medium molecular weight (MMW) hexamers, and high molecular weight (HMW) multimers (12 to 18 mers) (Pajvani et al., 2003). Importantly, plasma HMW multimers are related to insulin sensitivity, while failure in multimerarization of adiponectin is associated in patients with type 2 diabetes mellitus (Waki et al., 2003). Two isoforms of adiponectin receptor have been identified: AdipoR1 and AdipoR2 (Yamauchi et al., 2003). AdipoR1 is expressed primarily in skeletal muscle and is activated by AMPK phosphorylation, whereas AdipoR2 occurs mainly in the liver and is involved in the activation of peroxisome proliferator activating receptor alpha (PPAR- $\alpha$ ) (Lee et al., 2008). Furthermore, we found significantly higher plasma levels of adiponectin in patients with AN when compared with healthy women. Indeed, increased production of adiponectin may contribute to increased insulin sensitivity in patients with AN (Dostálová et al., 2006). Our observations of a 
negative correlation between plasma adiponectin levels and plasma insulin levels in patients with AN confirm the relationship between adiponectin and insulin sensitivity. Therefore, insulin is an important regulator of adiponectin and it was documented that prolonged exposure of insulin leads to a decrease in levels of adiponectin gene expression in 3T3-L1 adipocytes in vitro (Fasshauer et al., 2002). From the viewpoint of clinical medicine appears to be an important relationship of adiponectin to the development of insulin resistance and atherosclerosis. Indeed, adiponectin has a preventive effect against the development of atherosclerosis by preventing the transformation of macrophage foam cells and reduces the expression of surface adhesion molecules on macrophages, which affects the early stages of atherosclerotic plaque formation in humans (Okamoto et al., 2000). It is assumed that adiponectin increases insulin sensitivity and reduces risk of atherosclerosis. This hypothesis is supported by the fact that reduced plasma levels of adiponectin in human obesity will cause a reduction in insulin sensitivity, which is associated with the development of insulin resistance and type 2 diabetes mellitus (Nedvídková et al., 2005; Skop et al., 2009). Adiponectin secretion is up-regulated via PPAR-gamma $(\gamma)$ agonists such as the anti-diabetic drugs thiazolidinediones (TZDs). PPAR- $\gamma$ mediated adiponectin up-regulation is a mechanism contributing to improved insulin sensitivity shown in animal and human subjects treated with TZDs (Yamauchi and Kadowaki, 2008).

It was shown that estradiol is negatively and indirectly associated with adiponectin, whereas there is no association between serum adiponectin and leptin, cortisol, or free testosterone levels in humans (Gavrila et al., 2003). However, Nishizawa et al. (2002) documented that testosterone leads to a reduction in plasma adiponectin in men.

In contrast to leptin, which has been suggested to enter the brain via endocytosis through the leptin receptor, the mechanism by which adiponectin is able to reach the hypothalamus is unknown. Importantly, this study also showed that leptin sensitivity is markedly increased in adipo-/-mice leading to the proposal that the central actions of leptin and adiponectin have reciprocal functions to provide a homeostatic mechanism to maintain energy stores through the suppression or stimulation of appetite and energy expenditure (Kubota et al., 2007).

It was reported that a selective cannabinoid CB1 receptor antagonist rimonabant stimulated adiponectin mRNA expression in AT and reduced body weight in obese rats (Bensaid et al., 2003). In obese patients, the CB1 receptor blocker rimonabant upregulated adiponectin mRNA expression in omental AT explants (Ge et al., 2013). Likewise, obese and diabetic patients treated with $20 \mathrm{mg}$ rimonabant daily exhibited an increase in adiponectin levels (Després et al., 2005, 2009; Rosenstock et al., 2008). However, rimonabant and other blood-brain barrier penetrant CB1 receptor antagonists exert serious psychiatric side effects in obese patients (Christensen et al., 2007). It is noteworthy that novel non-brain-penetrant CB1 receptor antagonists URB447, JD-2114, and AM6545 (McElroy et al., 2008; LoVerme 
et al., 2009; Cluny et al., 2010) have recently been developed to produce many of the beneficial metabolic and anti-obesity effects of the prototypical CB1 receptor antagonist rimonabant and thus devoid of central side effects.

It was documented that administration of recombinant adiponectin can reverse obesity and obesity-related pathological conditions in animals (Li et al., 2012). However, there is currently no direct clinical evidence that adiponectin is effective in treating obese humans and obesity-related cardiometabolic diseases (Li et al., 2012). Furthermore, recent evidence showing association of higher adiponectin levels with heart failure and mortality in patients with stable ischaemic heart disease (Beatty et al., 2012). Indeed, adiponectin may be associated with the obesity paradox (Flegal et al., 2013), which indicates that obese patients may demonstrate lower all-cause and cardiovascular mortality when compared with normal-weight individuals (Hainer and Aldhood-Hainerová, 2013).

\section{Adipolin}

Adipolin (CTRP12) is a novel adipose-derived insulin-sensitizing adipokine (Enomoto et al., 2011). Adipolin (CTRP12) circulates in human and mouse plasma in two isoforms: full length fCTRP12 $(40 \mathrm{kDa})$ and a cleaved gCTRP12 (25 kDa). In plasma, gCTRP12 $(25 \mathrm{kDa})$ is the predominant isoform (Wei et al., 2012). Enhancement of insulin signalling by adipolin was noted through increased phosphorylation of the insulin signalling proteins (insulin receptor substrate [IRS-1, 2], serine/threonine kinase [Akt], and mitogen-activated protein kinase [MAPK]) (Wei et al., 2012). A negative correlation between adipolin levels and pro-inflammatory hormone resistin was reported (Wei et al., 2012). Plasma adipolin levels are diminished in obese mice and administration of adipolin leads to improved insulin sensitivity and glucose tolerance in obese and diabetic animal models (Wei et al., 2012). Moreover, adipolin reduces macrophage infiltration in AT and may decrease pro-inflammatory cytokines. This suggests an anti-inflammatory role of adipolin in obese and insulin resistant state (Enomoto et al., 2011).

To date there has been limited study of adipolin in humans. Tan et al. (2014) investigated the effect of metformin treatment on plasma adipolin levels in humans. They conclude that increase of plasma adipolin levels might constitute a novel pharmacological approach in the treatment of insulin resistant states.

\section{Visfatin}

Visfatin was described as a $52 \mathrm{kDa}$ pre-B cell colony-enhancing factor (PBEF) and expressed in peripheral blood lymphocytes (Samal et al., 1994). It was renamed and identified as a new adipokine "visfatin" because its production is higher in visceral AT when compared to subcutaneous AT (Fukuhara et al., 2005). Moreover, plasma visfatin levels are correlated positively with visceral AT mass. Ziora et al. (2012) documented that plasma visfatin levels were decreased in AN patients when compared with healthy controls. Instead, Dostálová et al. (2009) reported 
that plasma visfatin levels were not affected by the presence of both chronic malnutrition in AN or bingeing/purging behaviour in $\mathrm{BN}$ patients.

Similarly to insulin, visfatin in vitro enhanced glucose uptake by adipocytes and myocytes, and amplified adipocyte differentiation, and inhibited hepatocyte glucose release (Fukuhara et al., 2005). Visfatin insulin-like effects are observed in the phosphorylation of insulin receptors IRS-1 and IRS-2. Interestingly, visfatin and insulin have the same affinity for insulin receptor, but interacting with insulin receptor at different site. Visfatin plasma levels are elevated in patients with type 2 diabetes, while fasting visfatin levels tended to be lower in patients with type 1 diabetes (Kralisch et al., 2005; Chen et al., 2006). It has been shown that plasma visfatin levels increase with progressive beta cell deterioration in type 2 diabetes (López-Bermejo et al., 2006).

It is important to note that visfatin has a structure identical to two molecules, the extracellular form of the PBEF and the intracellular form of the nicotinamide phosphoribosyl-transferase (NAMPT). Thus, visfatin was rediscovered as the key enzyme of nicotinamide adenine dinucleotide (NAD) biosynthesis. Indeed, visfatin (or NAMPT) regulates intracellular activity of the NAD/NADH dependent enzymes that are critical for glucose-stimulated insulin secretion in pancreatic beta cells (Revollo et al., 2007).

Finally, neutralizing the actions of visfatin may bring benefits in models of inflammation, metabolic and inflammatory diseases and in the development of atherosclerosis (Moschen et al., 2010; Romacho et al., 2013).

\section{Omentin}

Omentin is a $38-40 \mathrm{kDa}$ novel adipokine preferentially produced by visceral AT and predominantly expressed in the SVF of visceral AT (Yang et al., 2006). Omentin (or intelectin-1) was originally identified as a soluble galactofuranosebinding lectin (Tsuji et al., 2001). It was documented that omentin enhances insulin-stimulated glucose uptake in human adipocytes through Akt signalling in vitro and that expression of omentin in visceral AT is reduced in obesity and insulin resistance (Yang et al., 2006; de Souza Batista et al., 2007). Furthermore, it was shown that animal and human endothelial cells treated with omentin led to vasodilatation through endothelium-derived nitric oxide (NO) and to suppression of TNF- $\alpha$ induced vascular inflammation (Yamawaki et al., 2010, 2011). Likewise, Tan et al. (2010) reported that omentin decreased in vitro migration and angiogenesis in human endothelial cells induced by human sera,VEGF, and C-reactive protein (CRP), and TNF- $\alpha$ induced activation of the nuclear factor kappa-light-chain enhancer of activated $B$ cells (NF- $\kappa B$ ).

In fact, omentin is highly expressed in perivascular AT and epicardial AT (Sacks and Fain, 2007). Thus, omentin may play a protective role in coronary atherosclerosis, obesity-related cardiovascular disorders, and hypertension, given the vasodilatating effect of omentin on blood vessels (Fain et al., 2008; Yamawaki et al., 2010). 
Brunetti et al. (2013) suggest that omentin may be involved in regulation of appetite. Indeed, in rats, administration of omentin diminished the expression of cocaine- and amphetamine-regulated transcript (CART) and increased norepinephrine release in the hypothalamus. Thus, these observations propose central orexigenic function of peripheral omentin (Brunetti et al., 2013).

Recently, Oświęcimska et al. (2015) reported that serum omentin levels are significantly higher in AN and significantly lower in obesity when compared with healthy subjects. Moreover, serum omentin levels correlated negatively with BMI, serum insulin, and HOMA-IR index. They conclude that omentin is the nutritional marker reflecting body weight and insulin resistance (Oświęcimska et al., 2015).

Finally, Herder et al. (2015) suggest that omentin acts via upregulation of adiponectin, which in turn affects lipid metabolism and thereby also indirectly enhances insulin sensitivity in humans.

Tumour necrosis factor-alpha (TNF- $\alpha$ )

TNF- $\alpha$ is synthesized as a $26 \mathrm{kDa}$ transmembrane protein that undergoes cleavage by a metalloproteinase to be released into the circulation as a $17 \mathrm{kDa}$ protein (Kriegler et al., 1988). In 1993, it was found that TNF- $\alpha$ is produced by adipocytes in obese mice (Hotamisligil et al., 1993) and this first adipose-derived factor suggested to represent a link between obesity, inflammation and diabetes. These experimental results were confirmed by the later work which showed that the increased production of pro-inflammatory cytokine TNF- $\alpha$ in human adipocytes was correlated positively with the degree of obesity, insulin levels and insulin resistance (Kern et al., 2001). However, it was recognized that adipocytes are not the major source of TNF- $\alpha$ in obesity but that macrophages from the SVF are the primary source of adipose-derived TNF- $\alpha$ and that higher plasma levels of TNF- $\alpha$ in obesity are due to the increased infiltration of AT with M1 macrophages (Weisberg et al., 2003).

Mechanism of action of TNF- $\alpha$ in AT is autocrine via insulin signalling cascade, TNF-alpha induces phosphorylation of the IRS-1 and thus prevents the interaction of insulin with an insulin receptor (Paz et al., 1997). Further, TNF- $\alpha$ enhances activity of hormone sensitive lipase (HSL) in AT and thus increases the release of FFA into circulation leading to the insulin resistance in the liver and skeletal muscle (Zahorska-Markiewicz, 2006). An interesting finding was that the administration of TNF- $\alpha$ suppresses insulin-sensitizing effect of adiponectin and increases leptin receptor action, whereas administration of adiponectin attenuates insulin resistance induced by administration of TNF- $\alpha$ (Maeda et al., 2002; Gan et al., 2012). Furthermore, neutralization of TNF- $\alpha$ with an antibody against TNF- $\alpha$ did not improve insulin sensitivity in type 2 diabetes mellitus (Ofei et al., 1996), while neutralization of TNF- $\alpha$ improved insulin resistance in patients with rheumatoid arthritis (Gonzales-Gay et al., 2006). 
TNF- $\alpha$ may play a direct role in the development of atherosclerosis through induction of adhesion molecule expression (vascular cell adhesion molecule-1 [VCAM-1], intercellular adhesion molecule-1 [ICAM-1], monocyte chemotactic protein-1 [MCP-1], and E-selectin) in endothelial and vascular smooth muscle cells resulting in endothelial cell apoptosis (Choy et al., 2001).

Interleukin-6 (IL-6)

IL-6 circulates in multiple glycosylated forms ranging from 22 to $27 \mathrm{kDa}$.

Approximately one third of circulating IL- 6 originates from AT (Mohamed-Ali et al., 1997). Secretion of IL-6 is 2 to 3 times greater in visceral relative to subcutaneous AT (Fontana et al., 2007). However, most of the adipose-derived IL-6 comes from SVF composed of endothelial cells, monocytes/macrophages, myocytes, and fibroblasts (Fain et al., 2004).

Plasma levels of IL-6 are elevated in patients with obesity and involved in the development of insulin resistance and type 2 diabetes (Pradhan et al., 2001; Klover et al., 2005). Infusion of recombinant IL-6 to human subjects leads to an increase in hepatic glucose output and hyperglycaemia; IL-6 has a lipolytic effect with a consequent increase of FFA levels in circulation (Polák et al., 2006). A pro-inflammatory cytokine IL-6 inhibits the insulin signalling cascade leading to an impairment of insulin-induced insulin receptor and IRS-1 phosphorylation (Senn et al., 2003). Experimental studies have confirmed that IL- 6 together with TNF- $\alpha$ decreased adiponectin mRNA in vitro (Bruun et al., 2003).

\section{Resistin}

Resistin is a $12.5 \mathrm{kDa}$ peptide produced by adipocytes in rats, whereas in humans it is synthesized by immunocompetent cells. Resistin belongs to the family of resistinlike molecules (RELMs), also known as "found in inflammatory zone" (FIZZ). It was hypothesized that resistin and its increased levels causes insulin resistance in obesity (Steppan et al., 2001). Administration of resistin in healthy mice impaired glucose tolerance, whereas immunoneutralization of resistin in mice with dietinduced obesity improved insulin sensitivity and glucose tolerance (Steppan and Lazar, 2002). Resistin levels in AT are significantly increased after administration of insulin (Kim et al., 2001). However, PPAR- $\gamma$ ligands such as TZDs inhibit resistin secretion (Rajala et al., 2004).

Resistin was considered to be a link between obesity, insulin resistance and diabetes. However, the role of resistin in human insulin resistance is less clear. In humans, resistin is more expressed in preadipocytes during adipogenesis than in mature adipocytes, in which its expression is negligible (McTernan et al., 2002). Some authors documented that plasma resistin levels are elevated in obese humans (Piestrzeniewicz et al., 2008), whereas other authors reported that high insulin-sensitive athletes have higher plasma resistin levels than obese subjects (Perseghin et al., 2006). In this vein, it was observed that testosterone increases 
the expression of resistin (Fonseca-Alaniz et al., 2007). However, there were not reported gender differences in plasma levels of resistin (Yannakoulia et al., 2003). Moreover, resistin has been shown to influence pro-inflammatory properties which may be associated with its production by resident monocytes/macrophages in AT in humans (Patel et al., 2003). On the contrary, low plasma resistin levels in AN patients (Ziora et al., 2011a, b) were probably related to a defective monocytemacrophage number and/or function (Dostálová et al., 2007), however resistin mRNA expression in AT of AN patients is increased (Dolezalova et al., 2007). Also further experimental studies in humans have produced inconsistent results and increased levels of resistin in obesity and especially its etiopathogenetical relationship to insulin resistance was not confirmed (Heilbronn et al., 2004; Housova et al., 2005; Anderlová et al., 2006; Dostálová et al., 2007).

It seems that the main significance of resistin in humans appears to regulate the inflammatory process by immunocompetent cells and adipocytes than directly influencing insulin sensitivity (Kusminski et al., 2005). Furthermore, resistin augments in endothelial cells the expression of endothelin-1, MCP-1, and cell adhesion molecules (ICAM-1,VCAM-1) (Verma et al., 2003; Kawanami et al., 2004). Human resistin also induces proliferation of aortic muscle cells (Calabro et al., 2004).

Finally, high resistin plasma levels are predictive of cardiovascular diseases such as coronary atherosclerosis (Reilly et al., 2005).

\section{Pigment epithelium-derived factor (PEDF)}

PEDF is a novel adipokine, which is a $50 \mathrm{kDa}$ secreted glycoprotein that belongs to the serine protease inhibitor (serpin) family (Becerra, 1997). It was first identified as a neurotrophic factor secreted by the human retinal pigment epithelial cells and is able to convert retinoblastoma tumour cells into differentiated non-proliferative neurons (Tombran-Tink et al., 1991). PEDF exerts its angio-inhibitory effect by modulating the vascular endothelial growth factor (VEGF) and its receptors (VEGFR1 and VEGFR2) (Cai et al., 2006). Famulla et al. (2011) found that PEDF is one of the most abundant adipokines released by adipocytes which is implicated in the development of insulin resistance, diabetes, and obesity-related disorders. Recombinant PEDF activates macrophages to release TNF- $\alpha$ and IL-1 (Chavan et al., 2012). It was shown that administration of recombinant PEDF reduced insulin sensitivity during hyperinsulinaemic-euglycaemic clamp in mice, whereas neutralisation of PEDF restored insulin sensitivity (Crowe et al., 2009).

PEDF promotes lipolysis in an adipose triglyceride lipase (ATGL)-dependent manner and mobilises FFA into systemic circulation leading to inflammation and ectopic lipid deposition. ATGL serves as a putative PEDF receptor (Zimmermann et al., 2004). PEDF acts to provoke kinase-mediated inhibitory Ser/ Thr phosphorylation cascade of IRS that attenuates insulin signalling and induces 
insulin resistance in peripheral tissues (Boura-Halfon and Zick, 2009). Hence, PEDF is adequate to initiate inhibitory array of Ser/Thr phosphorylation cascade to attenuate insulin signalling and induce insulin resistance in peripheral tissues. Moreover, it was shown that PEDF expression in AT positively correlates with obesity and insulin resistance in mice (Crowe et al., 2009).

Finally, inflammation, FFA mobilisation, and mitochondrial dysfunction are proposed mechanism of PEDF mediated insulin resistance. Thus, PEDF may be a potential therapeutic target in ameliorating insulin resistance (Carnagarin et al., 2015).

\section{Progranulin (PGRN)}

PGRN was identified as a pro-inflammatory adipokine that is abundantly expressed in adipocytes and macrophages in AT and involved in the development of insulin resistance and obesity (Matsubara et al., 2012). PGRN is a 66-68 kDa secreted glycoprotein, also known as proepithelin cell-derived growth factor (PCDGF), has been shown to be a pluripotent growth factor that plays a role in cell-cycle progression, angiogenesis, wound healing, cancers, and neurodegenerative diseases (He and Bateman, 2003; Feng et al., 2010).

Interestingly, it was documented that inhibition of hypothalamic PGRN expression increased food intake and promoted weight gain in rodents (Kim et al., 2011). Thus, an endogenous PGRN may function as an appetite suppressor in the hypothalamus. These data show that PGRN could function as a cytokine participating in regulation of food intake and energy balance.

TNF- $\alpha$ and dexamethasone treatment increase PGRN levels in adipocytes (Matsubara et al., 2012). Moreover, PGRN was documented as a ligand that binds to the TNF- $\alpha$ receptors (Tang et al., 2011). Thus, PGRN is a key adipokine that promotes insulin resistance by increasing levels of IL-6 and inhibiting insulin signalling cascade (Matsubara et al., 2012).

$\mathrm{Li}$ et al. (2014) reported that serum PGRN levels were significantly higher in patients with metabolic syndrome and correlated positively with BMI, fasting insulin, fasting plasma glucose, glycated haemoglobin A1c, triglyceride, and homeostasis model assessment of insulin resistance (HOMA-IR), and were inversely related to HDL cholesterol. Collectively, these findings suggest that circulating PGRN is significantly associated with systemic insulin sensitivity.

\section{Conclusion}

Taken together, it is now generally accepted that AT is an active secretory organ and its products affect a wide variety of central and peripheral organs such as the brain, liver, pancreas, and skeletal muscle. AT-sympathetic nervous systemhypothalamus serves as a feedback loop through sensory inflow informs the brain of the short- and long-term peripheral energy status. Therefore, dysregulation of pro-inflammatory and anti-inflammatory adipokines contributes to the 
development of metabolic and cardiovascular disorders. Leptin, adiponectin, adipolin, omentin, and visfatin show beneficial effects on insulin action and lipid metabolism. However, there are still many discrepancies between resistin results in animal models and humans and the molecular mechanism by which resistin exerts its detrimental effect on insulin action. Moreover, AT in the obese state is infiltrated by inflamed M1 macrophages that release TNF- $\alpha$ and IL- 6 with insulinresistant effect. Adipose-derived PEDF is a pro-inflammatory mediator, elevated in obesity, and implicated in the development of insulin resistance (Famulla et al., 2011). PGRN may function as a potential link between chronic inflammation and insulin resistance (Li et al., 2014). Also, omentin is a novel depot-specific adipokine in human AT with insulin-sensitizing effects and anti-inflammatory properties (Yang et al., 2006; Proença et al., 2014).

The strong correlations between AT and the secretion of adipokines has led to suggestion that the loss of AT mass may be strategy for the treatment of obesityrelated disorders. However, ablation of AT leads to severe insulin resistance in patients with lipoatrophic diabetes (Reitman et al., 1999).

Importantly, the primary treatment of obesity and its cardiometabolic health risks should be visceral AT and fat localized within organs such as the liver, skeletal muscle, and pancreatic beta cells and not subcutaneous fat which could play a protective role with regard to metabolic complications of obesity, particularly if placed over the hips and buttocks. Indeed, gluteofemoral subcutaneous AT is associated with metabolic protection. High thigh adiposity is associated with lower glucose and triglycerides, higher HDL, insulin sensitivity, and decreased risk for the metabolic syndrome and type 2 diabetes (Manolopoulos et al., 2010; McLaughlin et al., 2011; Karpe and Pinnick, 2015).

Further understanding of the endocrine function of AT and monocyte/ macrophage recruitment from the circulation as well as macrophage polarization will open potential pharmacological treatment strategies and therapeutic tools in metabolic abnormalities associated with obesity and malnutrition.

\section{References}

Ahima, R. S., Prabakaran, D., Mantzoros, C., Qu, D., Lowell, B., Maratos-Flier, E., Flier, J. S. (1996) Role of leptin in the neuroendocrine response to fasting. Nature 382, 250-252.

Anderlová, K., Křemen, J., Doležalová, R., Housová, J., Haluzíková, D., Kunešová, M., Haluzík, M. (2006) The influence of very-low-calorie-diet on serum leptin, soluble leptin receptor, adiponectin and resistin levels in obese women. Physiol. Res. 55, 277-283.

Arnoldussen, I. A., Kiliaan, A. J., Gustafson, D. R. (2014) Obesity and dementia:Adipokines interact with the brain. Eur. Neuropsychopharmacol. 24, 1982-1999.

Beatty, A. L., Zhang, M. H., Ku, I. A., Na, B., Schiller, N. B., Whooley, M. A. (2012) Adiponectin is associated with increased mortality and heart failure in patients with stable ischemic heart disease: data from the Heart and Soul Study. Atherosclerosis 220, 587-592.

Becerra, S. P. (1997) Structure-function studies on PEDF. A noninhibitory serpin with neurotrophic activity. Adv. Exp. Med. Biol. 425, 223-237. 
Bensaid, M., Gary-Bobo, M., Esclangon, A., Maffrand, J. P., Le Fur, G., Oury-Donat, F., Soubrié, P. (2003) The cannabinoid CB1 receptor antagonist SR141716 increases Acrp30 mRNA expression in adipose tissue of obese fa/fa rats and in cultured adipocyte cells. Mol. Pharmacol. 63, 908-914.

Bjørbaek, C., Elmquist, J. K., Frantz, J. D., Shoelson, S. E., Flier, J. S. (1998) Identification of SOCS-3 as a potential mediator of central leptin resistance. Mol. Cell 1, 619-625.

Bjørbaek, C., Kahn, B. B. (2004) Leptin signaling in the central nervous system and the periphery. Recent Prog. Horm. Res. 59, 305-331.

Booth, A., Magnuson, A., Foster, M. (2014) Detrimental and protective fat: body fat distribution and its relation to metabolic disease. Horm. Mol. Biol. Clin. Investig. 7, 13-27.

Boura-Halfon, S., Zick, Y. (2009) Phosphorylation of IRS proteins, insulin action, and insulin resistance. Am. J. Physiol. Endocrinol. Metab. 296, E581-E591.

Brochu-Gaudreau, K., Rehfeldt, C., Blouin, R., Bordignon, V., Murphy, B. D., Palin, M. F. (2010) Adiponectin action from head to toe. Endocrine 37, 11-32.

Brunetti, L., Orlando, G., Ferrante, C., Recinella, L., Leone, S., Chiavaroli, A., Di Nisio, C., Shohreh, R., Manippa, F., Ricciuti, A., Vacca, M. (2013) Orexigenic effects of omentin-1 related to decreased CART and CRH gene expression and increased norepinephrine synthesis and release in the hypothalamus. Peptides 44, 66-74.

Bruun, J. M., Lihn, A. S., Verdich, C., Pedersen, S. B., Toubro, S., Astrup, A., Richelsen, B. (2003) Regulation of adiponectin by adipose tissue-derived cytokines: in vivo and in vitro investigations in humans. Am. J. Physiol. Endocrinol. Metab. 285, E527-E533.

Cai, J., Jiang, W. G., Grant, M. B., Boulton, M. (2006) Pigment epithelium-derived factor inhibits angiogenesis via regulated intracellular proteolysis of vascular endothelial growth factor receptor 1. J. Biol. Chem. 281, 3604-3613.

Calabro, P., Samudio, I., Willerson, J. T., Yeh, E. T. (2004) Resistin promotes smooth muscle cell proliferation through activation of extracellular signal-regulated kinase $1 / 2$ and phosphatidylinositol 3-kinase pathways. Circulation 110, 3335-3340.

Campfield, L. A., Smith, F. J., Guisez, Y., Devos, R., Burn, P. (1995) Recombinant mouse OB protein: evidence for a peripheral signal linking adiposity and central neural networks. Science 269, 546-549.

Cao, H. (2014) Adipocytokines in obesity and metabolic disease. J. Endocrinol. 220, T47-T59.

Carnagarin, R., Dharmarajan, A. M., Dass, C. R. (2015) PEDF-induced alteration of metabolism leading to insulin resistance. Mol. Cell. Endocrinol. 401C, 98-104.

Chan, J. L., Heist, K., DePaoli, A. M., Veldhuis, J. D., Mantzoros, C. S. (2003) The role of falling leptin levels in the neuroendocrine and metabolic adaptation to short-term starvation in healthy men. J. Clin. Invest. 111, 1409-1421.

Chavan, S. S., Hudson, L. K., Li, J. H., Ochani, M., Harris, Y., Patel, N. B., Katz, D., Scheinerman, J. A., Pavlov, V.A., Tracey, K. J. (2012) Identification of pigment epithelium-derived factor as an adipocyte-derived inflammatory factor. Mol. Med. 18, 1161-1168.

Chen, M. P., Chung, F. M., Chang, D. M., Tsai, J. C., Huang, H. F., Shin, S. J., Lee, Y. J. (2006) Elevated plasma level of visfatin/pre-B cell colony-enhancing factor in patients with type 2 diabetes mellitus. J. Clin. Endocrinol. Metab. 91, 295-299.

Cheng, A., Uetani, N., Simoncic, P. D., Chaubey, V. P., Lee-Loy, A., McGlade, C. J., Kennedy, B. P., Tremblay, M. L. (2002) Attenuation of leptin action and regulation of obesity by protein tyrosine phosphatase 1B. Dev. Cell 4, 497-503.

Choy, J. C., Granville, D. J., Hunt, D.W., McManus, B. M. (2001) Endothelial cell apoptosis: biochemical characteristics and potential implications for atherosclerosis. J. Mol. Cell. Cardiol. 33, 1673-1690.

Christensen, R., Kristensen, P. K., Bartels, E. M., Bliddal, H., Astrup, A. (2007) Efficacy and safety of the weightloss drug rimonabant: a meta-analysis of randomised trials. Lancet 370, 1706-1713. 
Cluny, N. L., Vemuri, V. K., Chambers, A. P., Limebeer, C. L., Bedard, H., Wood, J. T., Lutz, B., Zimmer, A., Parker, L. A., Makriyannis, A., Sharkey, K. A. (2010) A novel peripherally restricted cannabinoid receptor antagonist, AM6545, reduces food intake and body weight, but does not cause malaise, in rodents. Br.J. Pharmacol. 161, 629-642.

Crowe, S., Wu, L. E., Economou, C., Turpin, S. M., Matzaris, M., Hoehn, K. L., Hevener, A. L., James, D. E., Duh, E. J., Watt, M. J. (2009) Pigment epithelium-derived factor contributes to insulin resistance in obesity. Cell Metab. 10, 40-47.

de Souza Batista, C. M., Yang, R. Z., Lee, M. J., Glynn, N. M., Yu, D. Z., Pray, J., Ndubuizu, K., Patil, S., Schwartz, A., Kligman, M., Fried, S. K., Gong, D.W., Shuldiner, A. R., Pollin, T. I., McLenithan, J. C. (2007) Omentin plasma levels and gene expression are decreased in obesity. Diabetes 56, 1655-1661.

Després, J. P., Golay, A., Sjöström, L. (2005) Effects of rimonabant on metabolic risk factors in overweight patients with dyslipidemia. Rimonabant in Obesity-Lipids Study Group. N. Engl. J. Med. 353, 2121-2134.

Després, J. P., Ross, R., Boka, G., Alméras, N., Lemieux, I. (2009) Effect of rimonabant on the high-triglyceride/ low-HDL-cholesterol dyslipidemia, intraabdominal adiposity, and liver fat: the ADAGIO-Lipids trial. ADAGIO-Lipids Investigators. Arterioscler. Thromb. Vasc. Biol. 29, 416-423.

Dolezalova, R., Lacinova, Z., Dolinkova, M., Kleiblova, P., Haluzikova, D., Housa, D., Papezova, H., Haluzik, M. (2007) Changes of endocrine function of adipose tissue in anorexia nervosa: comparison of circulating levels versus subcutaneous mRNA expression. Clin. Endocrinol. (Oxf.) 67, 674-678.

Dostálová, I., Smitka, K., Papežová, H., Kvasničková, H., Nedvídková, J. (2006) The role of adiponectin in increased insulin sensitivity of patients with anorexia nervosa. Vnitr. Lek. 52, 887-890.

Dostálová, I., Smitka, K., Papežová, H., Kvasničková, H., Nedvídková, J. (2007) Increased insulin sensitivity in patients with anorexia nervosa: the role of adipocytokines. Physiol. Res. 56, 587-594.

Dostálová, I., Sedláčková, D., Papežová, H., Nedvídková, J., Haluzík, M. (2009) Serum visfatin levels in patients with anorexia nervosa and bulimia nervosa. Physiol. Res. 58, 903-907.

Dubern, B., Clement, K. (2012) Leptin and leptin receptor-related monogenic obesity. Biochimie 94, 2111-2115.

Enomoto, T., Ohashi, K., Shibata, R., Higuchi, A., Maruyama, S., Izumiya, Y., Walsh, K., Murohara, T., Ouchi, N. (2011) Adipolin/C1qdc2/CTRP12 protein functions as an adipokine that improves glucose metabolism. J. Biol. Chem. 286, 34552-34558.

Esteve Ràfols, M. (2014) Adipose tissue: cell heterogeneity and functional diversity. Endocrinol. Nutr. 61, 100-112.

Exley, M., Hand, L. E., O'Shea, D., Lynch, L. (2014) The interplay between the immune system and adipose in obesity. J. Endocrinol. 223, R41-R48.

Fain, J. N., Madan, A. K., Hiler, M. L., Cheema, P., Bahouth, S.W. (2004) Comparison of the release of adipokines by adipose tissue, adipose tissue matrix, and adipocytes from visceral and subcutaneous abdominal adipose tissues of obese humans. Endocrinology 145, 2273-2282.

Fain, J. N., Sacks, H. S., Buehrer, B., Bahouth, S.W., Garrett, E., Wolf, R. Y., Carter, R. A., Tichansky, D. S., Madan, A. K. (2008) Identification of omentin mRNA in human epicardial adipose tissue: comparison to omentin in subcutaneous, internal mammary artery periadventitial and visceral abdominal depots. Int. J. Obes. (Lond.) 32, 810-815.

Famulla, S., Lamers, D., Hartwig, S., Passlack, W., Horrighs, A., Cramer, A., Lehr, S., Sell, H., Eckel, J. (2011) Pigment epithelium-derived factor (PEDF) is one of the most abundant proteins secreted by human adipocytes and induces insulin resistance and inflammatory signaling in muscle and fat cells. Int. J. Obes. (Lond.) 35, 762-772.

Farooqi, I. S., O’Rahilly, S. (2005) Monogenic obesity in humans. Annu. Rev. Med. 56, 443-458.

Farooqi, I. S., Jebb, S. A., Langmack, G., Lawrence, E., Cheetham, C. H., Prentice, A. M., Hughes, I. A., 
McCamish, M. A., O'Rahilly, S. (1999) Effects of recombinant leptin therapy in a child with congenital leptin deficiency. N. Engl. J. Med. 341, 879-884.

Farooqi, I. S., Matarese, G., Lord, G. M., Keogh, J. M., Lawrence, E., Agwu, C., Sanna, V., Jebb, S. A., Perna, F., Fontana, S., Lechler, R. I., DePaoli, A. M., O’Rahilly, S. (2002) Beneficial effects of leptin on obesity, T cell hyporesponsiveness, and neuroendocrine/metabolic dysfunction of human congenital leptin deficiency. J. Clin. Invest. 110, 1093-1103.

Fasshauer, M., Klein, J., Neumann, S., Eszlinger, M., Paschke, R. (2002) Hormonal regulation of adiponectin gene expression in 3T3-L1 adipocytes. Biochem. Biophys. Res. Commun. 290, 1084-1089.

Feng, J. Q., Guo, F. J., Jiang, B. C., Zhang, Y., Frenkel, S., Wang, D.W., Tang, W., Xie, Y., Liu, C. J. (2010) Granulin epithelin precursor: a bone morphogenic protein 2-inducible growth factor that activates Erk1/2 signaling and JunB transcription factor in chondrogenesis. FASEB J. 24, 1879-1892.

Flegal, K. M., Kit, B. K., Orpana, H., Graubard, B. I. (2013) Association of all-cause mortality with overweight and obesity using standard body mass index categories: a systematic review and meta-analysis. JAMA 309, 71-82.

Flier, J. S. (2004) Obesity wars: molecular progress confronts an expanding epidemic. Cell 116, 337-350.

Fonseca-Alaniz, M. H., Takada, J., Alonso-Vale, M. I., Lima, F. B. (2007) Adipose tissue as an endocrine organ: from theory to practice. J. Pediatr. 83, S192-S203.

Fontana, L., Eagon, J. C., Trujillo, M. E., Scherer, P. E., Klein, S. (2007) Visceral fat adipokine secretion is associated with systemic inflammation in obese humans. Diabetes 56, 1010-1013.

Friedman, J. (2014) 20 years of leptin: An overview. J. Endocrinol. 223, T1-T8.

Fukuhara, A., Matsuda, M., Nishizawa, M., Segawa, K., Tanaka, M., Kishimoto, K., Matsuki, Y., Murakami, M., Ichisaka, T., Murakami, H., Watanabe, E., Takagi, T., Akiyoshi, M., Ohtsubo, T., Kihara, S., Yamashita, S., Makishima, M., Funahashi, T., Yamanaka, S., Hiramatsu, R., Matsuzawa, Y., Shimomura, I. (2005) Visfatin: a protein secreted by visceral fat that mimics the effects of insulin. Science 307, 426-430.

Galic, S., Oakhill, J. S., Steinberg, G. R. (2010) Adipose tissue as an endocrine organ. Mol. Cell. Endocrinol. 316, 129-139.

Gan, L., Guo, K., Cremona, M. L., McGraw, T. E., Leibel, R. L., Zhang,Y. (2012) TNF- $\alpha$ up-regulates protein level and cell surface expression of the leptin receptor by stimulating its export via a PKC-dependent mechanism. Endocrinology 153, 5821-5833.

Gavrila, A., Chan, J. L., Yiannakouris, N., Kontogianni, M., Miller, L. C., Orlova, C., Mantzoros, C. S. (2003) Serum adiponectin levels are inversely associated with overall and central fat distribution but are not directly regulated by acute fasting or leptin administration in humans: cross-sectional and interventional studies. J. Clin. Endocrinol. Metab. 88, 4823-4831.

Ge, Q., Maury, E., Rycken, L., Gérard, J., Noël, L., Detry, R., Navez, B., Brichard, S. M. (2013) Endocannabinoids regulate adipokine production and the immune balance of omental adipose tissue in human obesity. Int. J. Obes. (Lond.) 37, 874-880.

Gonzalez-Gay, M.A., De Matias, J. M., Gonzalez-Juanatey, C., Garcia-Porrua, C., Sanchez-Andrade, A., Martin, J., Llorca, J. (2006) Anti-tumor necrosis factor-alpha blockade improves insulin resistance in patients with rheumatoid arthritis. Clin. Exp. Rheumatol. 24, 83-86.

Hainer, V., Aldhoon-Hainerová, I. (2013) Obesity paradox does exist. Diabetes Care 36, S276-S281 (Suppl. 2).

Hathout, E. H., Sharkey, J., Racine, M., Ahn, D., Mace, J.W., Saad, M. F. (1999) Changes in plasma leptin during the treatment of diabetic ketoacidosis. J. Clin. Endocrinol. Metab. 84, 4545-4548.

He, Z., Bateman, A. (2003) Progranulin (granulin-epithelin precursor, PC-cell-derived growth factor, acrogranin) mediates tissue repair and tumorigenesis. J. Mol. Med. (Berl.) 81, 600-612.

Heilbronn, L. K., Rood, J., Janderova, L., Albu, J. B., Kelley, D. E., Ravussin, E., Smith, S. R. (2004) Relationship 
between serum resistin concentrations and insulin resistance in nonobese, obese, and obese diabetic subjects. J. Clin. Endocrinol. Metab. 89, 1844-1848.

Herder, C., Ouwens, D. M., Carstensen, M., Kowall, B., Huth, C., Meisinger, C., Rathmann, W., Roden, M., Thorand, B. (2015) Adiponectin may mediate the association between omentin, circulating lipids and insulin sensitivity: results from the KORA F4 study. Eur. J. Endocrinol. 172, 423-432.

Heymsfield, S. B., Greenberg, A. S., Fujioka, K., Dixon, R. M., Kushner, R., Hunt, T., Lubina, J. A., Patane, J., Self, B., Hunt, P., McCamish, M. (1999) Recombinant leptin for weight loss in obese and lean adults: a randomized, controlled, dose-escalation trial. JAMA 282, 1568-1575.

Hileman, S. M., Pierroz, D. D., Flier, J. S. (2000) Leptin, nutrition, and reproduction: timing is everything. J. Clin. Endocrinol. Metab. 85, 804-807.

Hotamisligil, G. S., Shargill, N. S., Spiegelman, B. M. (1993) Adipose expression of tumor necrosis factor-alpha: direct role in obesity-linked insulin resistance. Science 259, 87-91.

Hotta, K., Funahashi, T., Arita, Y., Takahashi, M., Matsuda, M., Okamoto, Y., Iwahashi, H., Kuriyama, H., Ouchi, N., Maeda, K., Nishida, M., Kihara, S., Sakai, N., Nakajima, T., Hasegawa, K., Muraguchi, M., Ohmoto, Y., Nakamura, T., Yamashita, S., Hanafusa, T., Matsuzawa, Y. (2000) Plasma concentrations of a novel, adiposespecific protein, adiponectin, in type 2 diabetic patients. Arterioscler. Thromb. Vasc. Biol. 20, 1595-1599.

Hotta, K., Funahashi, T., Bodkin, N. L., Ortmeyer, H. K., Arita, Y., Hansen, B. C., Matsuzawa, Y. (2001) Circulating concentrations of the adipocyte protein adiponectin are decreased in parallel with reduced insulin sensitivity during the progression to type 2 diabetes in rhesus monkeys. Diabetes 50,1126-1133.

Housova, J., Anderlova, K., Krizova, J., Haluzikova, D., Kremen, J., Kumstyrova, T., Papezova, H., Haluzik, M. (2005) Serum adiponectin and resistin concentrations in patients with restrictive and binge/purge form of anorexia nervosa and bulimia nervosa. J. Clin. Endocrinol. Metab. 90, 1366-1370.

Hu, E., Liang, P., Spiegelman, B. M. (1996) AdipoQ is a novel adipose-specific gene dysregulated in obesity. J. Biol. Chem. 271, 10697-10703.

Hukshorn, C. J., Saris, W. H., Westerterp-Plantenga, M. S., Farid, A. R., Smith, F. J., Campfield, L. A. (2000) Weekly subcutaneous pegylated recombinant native human leptin (PEG-OB) administration in obese men. J. Clin. Endocrinol. Metab. 85, 4003-4009.

Hukshorn, C. J., van Dielen, F. M., Buurman, W. A., Westerterp-Plantenga, M. S., Campfield, L. A., Saris, W. H. (2002) The effect of pegylated recombinant human leptin (PEG-OB) on weight loss and inflammatory status in obese subjects. Int. J. Obes. Relat. Metab. Disord. 26, 504-509.

Ibrahim, M. M. (2010) Subcutaneous and visceral adipose tissue: structural and functional differences. Obes. Rev. 11, 11-18.

Karpe, F., Pinnick, K. E. (2015) Biology of upper-body and lower-body adipose tissue-link to whole-body phenotypes. Nat. Rev. Endocrinol. 11, 90-100.

Kawanami, D., Maemura, K., Takeda, N., Harada, T., Nojiri, T., Imai, Y., Manabe, I., Utsunomiya, K., Nagai, R. (2004) Direct reciprocal effects of resistin and adiponectin on vascular endothelial cells: a new insight into adipocytokine-endothelial cell interactions. Biochem. Biophys. Res. Commun. 314, 415-419.

Kern, P. A., Ranganathan, S., Li, C., Wood, L., Ranganathan, G. (2001) Adipose tissue tumor necrosis factor and interleukin-6 expression in human obesity and insulin resistance. Am. J. Physiol. Endocrinol. Metab. 280, E745-E751.

Kershaw, E. E., Flier, J. S. (2004) Adipose tissue as an endocrine organ. J. Clin .Endocrinol. Metab. 89, 2548-2556.

Kim, H. K., Shin, M. S., Youn, B. S., Namkoong, C., Gil, S. Y., Kang, G. M., Yu, J. H., Kim, M. S. (2011) Involvement of progranulin in hypothalamic glucose sensing and feeding regulation. Endocrinology 152, 4672-4682.

Kim, K. H., Lee, K., Moon, Y. S., Sul, H. S. (2001) A cysteine-rich adipose tissue-specific secretory factor inhibits adipocyte differentiation. J. Biol. Chem. 276, 11252-11256. 
Kitabchi, A. E., Umpierrez, G. E. (2003) Changes in serum leptin in lean and obese subjects with acute hyperglycemic crises. J. Clin. Endocrinol. Metab. 88, 2593-2596.

Klover, P. J., Clementi, A. H., Mooney, R. A. (2005) Interleukin-6 depletion selectively improves hepatic insulin action in obesity. Endocrinology 146, 3417-3427.

Knights, A. J., Funnell, A. P., Pearson, R. C., Crossley, M., Bell-Anderson, K. S. (2014) Adipokines and insulin action: A sensitive issue. Adipocyte 3, 88-96.

Kralisch, S., Klein, J., Lossner, U., Bluher, M., Paschke, R., Stumvoll, M., Fasshauer, M. (2005) Hormonal regulation of the novel adipocytokine visfatin in 3T3-L1 adipocytes. J. Endocrinol. 185, R1-R8.

Kratzsch, J., Knerr, I., Galler, A., Kapellen, T., Raile, K., Körner, A., Thiery, J., Dötsch, J., Kiess, W. (2006) Metabolic decompensation in children with type 1 diabetes mellitus associated with increased serum levels of the soluble leptin receptor. Eur. J. Endocrinol. 155, 609-614.

Kriegler, M., Perez, C., DeFay, K., Albert, I., Lu, S. D. (1988) A novel form of TNF/cachectin is a cell surface cytotoxic transmembrane protein: ramifications for the complex physiology of TNF. Cell 53, 45-53.

Kubota, N., Yano, W., Kubota, T., Yamauchi, T., Itoh, S., Kumagai, H., Kozono, H., Takamoto, I., Okamoto, S., Shiuchi, T., Suzuki, R., Satoh, H., Tsuchida, A., Moroi, M., Sugi, K., Noda, T., Ebinuma, H., Ueta, Y., Kondo, T., Araki, E., Ezaki, O., Nagai, R., Tobe, K., Terauchi, Y., Ueki, K., Minokoshi, Y., Kadowaki, T. (2007) Adiponectin stimulates AMP-activated protein kinase in the hypothalamus and increases food intake. Cell Metab. 6 , 55-68.

Kusminski, C. M., McTernan, P. G., Kumar, S. (2005) Role of resistin in obesity, insulin resistance and type II diabetes. Clin. Sci. 109, 243-256.

Lee, M. H., Klein, R. L., El-Shewy, H. M., Luttrell, D. K., Luttrell, L. M. (2008) The adiponectin receptors AdipoR1 and AdipoR2 activate ERK1/2 through a Src/Ras-dependent pathway and stimulate cell growth. Biochemistry 47, 11682-11692.

Li, F.Y., Lam, K. S., Xu, A. (2012) Therapeutic perspectives for adiponectin: an update. Curr. Med. Chem. 19, 5513-5523.

Li, H., Zhou, B., Xu, L., Liu, J., Zang, W., Wu, S., Sun, H. (2014) Circulating PGRN is significantly associated with systemic insulin sensitivity and autophagic activity in metabolic syndrome. Endocrinology 155, 3493-3507.

Licinio, J., Caglayan, S., Ozata, M., Yildiz, B. O., de Miranda, P. B., O’Kirwan, F., Whitby, R., Liang, L., Cohen, P., Bhasin, S., Krauss, R. M., Veldhuis, J. D., Wagner, A. J., DePaoli, A. M., McCann, S. M., Wong, M. L. (2004) Phenotypic effects of leptin replacement on morbid obesity, diabetes mellitus, hypogonadism, and behavior in leptin-deficient adults. Proc. Natl. Acad. Sci. U. S. A. 101, 4531-4536.

López-Bermejo, A., Chico-Julià, B., Fernàndez-Balsells, M., Recasens, M., Esteve, E., Casamitjana, R., Ricart, W., Fernández-Real, J. M. (2006) Serum visfatin increases with progressive beta-cell deterioration. Diabetes 55, 2871-2875.

LoVerme, J., Duranti, A., Tontini, A., Spadoni, G., Mor, M., Rivara, S., Stella, N., Xu, C., Tarzia, G., Piomelli, D. (2009) Synthesis and characterization of a peripherally restricted CB1 cannabinoid antagonist, URB447, that reduces feeding and body-weight gain in mice. Bioorg. Med. Chem. Lett. 19, 639-643.

Lumeng, C. N., Bodzin, J. L., Saltiel, A. R. (2007) Obesity induces a phenotypic switch in adipose tissue macrophage polarization. J. Clin. Invest. 117, 175-184.

Maeda, K., Okubo, K., Shimomura, I., Funahashi, T., Matsuzawa, Y., Matsubara, K. (1996) cDNA cloning and expression of a novel adipose specific collagen-like factor, apM1 (AdiPose Most abundant Gene transcript 1). Biochem. Biophys. Res. Commun. 221, 286-289.

Maeda, N., Shimomura, I., Kishida, K., Nishizawa, H., Matsuda, M., Nagaretani, H., Furuyama, N., Kondo, H., Takahashi, M., Arita, Y., Komuro, R., Ouchi, N., Kihara, S., Tochino, Y., Okutomi. K., Horie, M., Takeda, S., Aoyama, T., Funahashi, T., Matsuzawa, Y. (2002) Diet-induced insulin resistance in mice lacking adiponectin/ ACRP30. Nat. Med. 8, 731-737. 
Manolopoulos, K. N., Karpe, F., Frayn, K. N. (2010) Gluteofemoral body fat as a determinant of metabolic health. Int. J. Obes. (Lond.) 34, 949-959.

Matsubara, T., Mita, A., Minami, K., Hosooka, T., Kitazawa, S., Takahashi, K., Tamori, Y., Yokoi, N., Watanabe, M., Matsuo, E., Nishimura, O., Seino, S. (2012) PGRN is a key adipokine mediating high fat diet-induced insulin resistance and obesity through IL-6 in adipose tissue. Cell Metab. 15, 38-50.

McElroy, J., Sieracki, K., Chorvat, R. (2008) Non-brain penetrant CB1 receptor antagonists as a novel treatment of obesity and related metabolic disorders. Obesity 16, S47 (Suppl. 1).

McLaughlin, T., Lamendola, C., Liu, A., Abbasi, F. (2011) Preferential fat deposition in subcutaneous versus visceral depots is associated with insulin sensitivity. J. Clin. Endocrinol. Metab. 96, E1756-E1760.

McTernan, P. G., McTernan, C. L., Chetty, R., Jenner, K., Fisher, F. M., Lauer, M. N., Crocker, J., Barnett, A. H., Kumar, S. (2002) Increased resistin gene and protein expression in human abdominal adipose tissue. J. Clin. Endocrinol. Metab. 87, 2407.

Mendoza-Núñez,V. M., García-Sánchez, A., Sánchez-Rodríguez, M., Galván-Duarte, R. E., Fonseca-Yerena, M. E. (2002) Overweight, waist circumference, age, gender, and insulin resistance as risk factors for hyperleptinemia. Obes. Res. 10, 253-259.

Minokoshi,Y., Kim, Y. B., Peroni, O. D., Fryer, L. G., Müller, C., Carling, D., Kahn, B. B. (2002) Leptin stimulates fatty-acid oxidation by activating AMP-activated protein kinase. Nature 415, 339-343.

Mohamed-Ali, V., Goodrick, S., Rawesh A., Katz, D. R., Miles, J. M., Yudkin, J. S., Klein, S., Coppack, S. W. (1997) Subcutaneous adipose tissue releases interleukin-6, but not tumor necrosis factor-alpha, in vivo. J. Clin. Endocrinol. Metab. 82, 4196-4200.

Moon, H. S., Dalamaga, M., Kim, S. Y., Polyzos, S. A., Hamnvik, O. P., Magkos, F., Paruthi, J., Mantzoros, C. S. (2013) Leptin's role in lipodystrophic and nonlipodystrophic insulin-resistant and diabetic individuals. Endocr. Rev. 34, 377-412.

Moschen, A. R., Gerner, R. R., Tilg, H. (2010) Pre-B cell colony enhancing factor/NAMPT/visfatin in inflammation and obesity-related disorders. Curr. Pharm. Des. 16, 1913-1920.

Münzberg, H., Myers, M. G. Jr. (2005) Molecular and anatomical determinants of central leptin resistance. Nat. Neurosci. 8, 566-570.

Nakano, Y., Tobe, T., Choi-Miura, N. H., Mazda, T., Tomita, M., Nakano, Y., Tobe, T., Choi-Miura, N. H., Mazda, T., Tomita, M. (1996) Isolation and characterization of GBP28, a novel gelatin-binding protein purified from human plasma. J. Biochem. 120, 803-812.

Nedvídková, J., Papežová, H., Haluzík, M., Schreiber, V. (2000) Interaction between serum leptin levels and hypothalamo-hypophyseal-thyroid axis in patients with anorexia nervosa. Endocr. Res. 26, 219-230.

Nedvídková, J., Smitka, K., Kopský, V., Hainer, V. (2005) Adiponectin, an adipocyte-derived protein. Physiol. Res. 54, 133-140.

Nishizawa, H., Shimomura, I., Kishida, K., Maeda, N., Kuriyama, H., Nagaretani, H., Matsuda, M., Kondo, H., Furuyama, N., Kihara, S., Nakamura, T., Tochino, Y., Funahashi, T., Matsuzawa, Y. (2002) Androgens decrease plasma adiponectin, an insulin-sensitizing adipocyte-derived protein. Diabetes 51, 2734-2741.

Nogueiras, R., Tschöp, M. H., Zigman, J. M. (2008) Central nervous system regulation of energy metabolism: ghrelin versus leptin. Ann. N.Y.Acad. Sci. 1126, 14-19.

Ofei, F., Hurel, S., Newkirk, J., Sopwith, M., Taylor, R. (1996) Effects of an engineered human anti-TNF-alpha antibody (CDP571) on insulin sensitivity and glycemic control in patients with NIDDM. Diabetes $\mathbf{4 5}$, 881-885.

Okamoto, Y., Arita, Y., Nishida, M., Muraguchi, M., Ouchi, N., Takahashi, M., Igura, T., Inui, Y., Kihara, S., Nakamura, T., Yamashita, S., Miyagawa, J., Funahashi, T., Matsuzawa, Y. (2000) An adipocyte-derived plasma protein, adiponectin, adheres to injured vascular walls. Horm. Metab. Res. 32, 47-50.

Oral, E. A. (2012) Leptin for type 1 diabetes: coming onto stage to be (or not?). Pediatr. Diabetes 13, 68-73. 
Oświęcimska, J., Suwała, A., Świętochowska, E., Ostrowska, Z., Gorczyca, P., Ziora-Jakutowicz, K., Machura, E., Szczepańska, M., Kukla, M., Stojewska, M., Ziora, D., Ziora, K. (2015) Serum omentin levels in adolescent girls with anorexia nervosa and obesity. Physiol. Res. (Epub ahead of print)

Pajvani, U. B., Du, X., Combs, T. P., Berg, A. H., Rajala, M.W., Schulthess, T., Engel, J., Brownlee, M., Scherer, P. E. (2003) Structure-function studies of the adipocyte-secreted hormone Acrp30/adiponectin. Implications for metabolic regulation and bioactivity. J. Biol. Chem. 278, 9073-9085.

Patel, L., Buckels, A. C., Kinghorn, I. J., Murdock, P. R., Holbrook, J. D., Plumpton, C., Macphee, C. H., Smith, S. A. (2003) Resistin is expressed in human macrophages and directly regulated by PPAR gamma activators. Biochem. Biophys. Res. Commun. 300, 472-476.

Paz, K., Hemi, R., LeRoith, D., Karasik, A., Elhanany, E., Kanety, H., Zick, Y. (1997) A molecular basis for insulin resistance. Elevated serine/threonine phosphorylation of IRS-1 and IRS-2 inhibits their binding to the juxtamembrane region of the insulin receptor and impairs their ability to undergo insulin-induced tyrosine phosphorylation. J. Biol. Chem. 272, 29911-29918.

Perry, R. J., Zhang, X. M., Zhang, D., Kumashiro, N., Camporez, J. P., Cline, G.W., Rothman, D. L., Shulman, G. I. (2014) Leptin reverses diabetes by suppression of the hypothalamic-pituitary-adrenal axis. Nat. Med. 20, 759-763.

Perseghin, G., Burska, A., Lattuada, G., Alberti, G., Costantino, F., Ragogna, F., Oggionni, S., Scollo, A., Terruzzi, I., Luzi, L. (2006) Increased serum resistin in elite endurance athletes with high insulin sensitivity. Diabetologia 49, 1893-1900.

Petersen, K. F., Oral, E. A., Dufour, S., Befroy, D., Ariyan, C., Yu, C., Cline, G.W., DePaoli, A. M., Taylor, S. I., Gorden, P., Shulman, G. I. (2002) Leptin reverses insulin resistance and hepatic steatosis in patients with severe lipodystrophy. J. Clin. Invest. 109, 1345-1350.

Piestrzeniewicz, K., Łuczak, K., Komorowski, J., Maciejewski, M., Jankiewicz Wika, J., Goch, J. H. (2008) Resistin increases with obesity and atherosclerotic risk factors in patients with myocardial infarction. Metabolism 57, 488-493.

Polák, J., Klimčáková, E., Kováčiková, M.,Vítková, M., Bajzová, M., Hejnová, J., Štich, V. (2006) The endocrine function of adipose tissue in the pathogenesis of insulin resistance. Interni Med. 10, 443-446. (in Czech)

Pradhan, A. D., Manson, J. E., Rifai, N., Buring, J. E., Ridker, P. M. (2001) C-reactive protein, interleukin 6, and risk of developing type 2 diabetes mellitus. JAMA 286, 327-334.

Proença, A. R., Sertié, R. A., Oliveira, A. C., Campaãa, A. B., Caminhotto, R. O., Chimin, P., Lima, F. B. (2014) New concepts in white adipose tissue physiology. Braz. J. Med. Biol. Res. 47, 192-205.

Purwata, T. E. (2011) High TNF-alpha plasma levels and macrophages iNOS and TNF-alpha expression as risk factors for painful diabetic neuropathy. J. Pain Res. 4, 169-175.

Rajala, M.W., Qi,Y., Patel, H. R., Takahashi, N., Banerjee, R., Pajvani, U. B., Sinha, M. K., Gingerich, R. L., Scherer, P. E., Ahima, R. S. (2004) Regulation of resistin expression and circulating levels in obesity, diabetes, and fasting. Diabetes 53, 1671-1679.

Reilly, M. P., Lehrke, M., Wolfe, M. L., Rohatgi, A., Lazar, M. A., Rader, D. J. (2005) Resistin is an inflammatory marker of atherosclerosis in humans. Circulation 111, 932-939.

Reitman, M. L., Mason, M. M., Moitra, J., Gavrilova, O., Marcus-Samuels, B., Eckhaus, M., Vinson, C. (1999) Transgenic mice lacking white fat: models for understanding human lipoatrophic diabetes. Ann. N.Y. Acad. Sci. 892, 289-296.

Revollo, J. R., Körner, A., Mills, K. F., Satoh, A., Wang, T., Garten, A., Dasgupta, B., Sasaki, Y., Wolberger, C., Townsend, R. R., Milbrandt, J., Kiess, W., Imai, S. (2007) Nampt/PBEF/Visfatin regulates insulin secretion in beta cells as a systemic NAD biosynthetic enzyme. Cell Metab. 6, 363-375.

Romacho, T., Sánchez-Ferrer, C. F., Peiró, C. (2013) Visfatin/Nampt: an adipokine with cardiovascular impact. Mediators Inflamm. 2013, 946427. 
Romacho, T., Elsen, M., Röhrborn, D., Eckel, J. (2014) Adipose tissue and its role in organ crosstalk. Acta Physiol. (Oxf.) 210, 733-753.

Rosenstock, J., Hollander, P., Chevalier, S., Iranmanesh, A. (2008) SERENADE: the Study Evaluating Rimonabant Efficacy in Drug-naive Diabetic Patients: effects of monotherapy with rimonabant, the first selective CB1 receptor antagonist, on glycemic control, body weight, and lipid profile in drug-naive type 2 diabetes. Diabetes Care 31, 2169-2176.

Sacks, H. S., Fain, J. N. (2007) Human epicardial adipose tissue: a review. Am. Heart J. 153, 907-917.

Sáinz, N., Barrenetxe, J., Moreno-Aliaga, M. J., Martínez, J. A. (2015) Leptin resistance and diet-induced obesity: central and peripheral actions of leptin. Metabolism 64, 35-46.

Samal, B., Sun, Y., Stearns, G., Xie, C., Suggs, S., McNiece, I. (1994) Cloning and characterization of the cDNA encoding a novel human pre-B-cell colony-enhancing factor. Mol. Cell. Biol. 14, 1431-1437.

Scherer, P. E., Williams, S., Fogliano, M., Baldini, G., Lodish, H. F. (1995) A novel serum protein similar to C1q, produced exclusively in adipocytes. J. Biol. Chem. 270, 26746-26749.

Senn, J. J., Klover, P. J., Nowak, I. A., Zimmers, T. A., Koniaris, L. G., Furlanetto, R. W., Mooney, R. A. (2003) Suppressor of cytokine signaling-3 (SOCS-3), a potential mediator of interleukin-6-dependent insulin resistance in hepatocytes. J. Biol. Chem. 278, 13740-13746.

Skop, V., Kontrova, K., Zidkova, J., Zidek, V. (2009) Adipocytokines: Recently discovered hormones of adipose tissue. Chem. Listy 103, 187-192.

Smitka, K., Papezova, H., Vondra, K., Hill, M., Hainer, V., Nedvidkova, J. (2011) A higher response of plasma neuropeptide $\mathrm{Y}$, growth hormone, leptin levels and extracellular glycerol levels in subcutaneous abdominal adipose tissue to Acipimox during exercise in patients with bulimia nervosa: single-blind, randomized, microdialysis study. Nutr. Metab. (Lond.) 8, 81.

Smitka, K., Papezova, H., Vondra, K., Hill, M., Hainer, V., Nedvidkova, J. (2013a) Short-term exercise combined with Acipimox administration induces an increase in plasma ACTH and its subsequent fall in the recovery phase in bulimic women. Regul. Pept. 182, 45-52.

Smitka, K., Papezova, H., Vondra, K., Hill, M., Hainer, V., Nedvidkova, J. (2013b) The role of “mixed” orexigenic and anorexigenic signals and autoantibodies reacting with appetite-regulating neuropeptides and peptides of the adipose tissue-gut-brain axis: relevance to food intake and nutritional status in patients with anorexia nervosa and bulimia nervosa. Int. J. Endocrinol. 2013, 483145.

Steppan, C. M., Bailey, S. T., Bhat, S., Brown, E. J., Banerjee, R. R., Wright, C. M., Patel, H. R., Ahima, R. S., Lazar, M.A. (2001) The hormone resistin links obesity to diabetes. Nature 409, 307-312.

Steppan, C. M., Lazar, M. A. (2002) Resistin and obesity-associated insulin resistance. Trends Endocrinol. Metab. 13, 18-23.

Szücs, N.,Varga, I., Jakab, C., Patócs, A., Gláz, E., Tóth, M., Kiss, R., Rácz, K. (2001) Leptin inhibits cortisol and corticosterone secretion in pathologic human adrenocortical cells. Pituitary 4, 71-77.

Tan, B. K., Adya, R., Farhatullah, S., Chen, J., Lehnert, H., Randeva, H. S. (2010) Metformin treatment may increase omentin-1 levels in women with polycystic ovary syndrome. Diabetes 59, 3023-3031.

Tan, B. K., Chen, J., Hu, J., Amar, O., Mattu, H. S., Ramanjaneya, M., Patel, V., Lehnert, H., Randeva, H. S. (2014) Circulatory changes of the novel adipokine adipolin/CTRP12 in response to metformin treatment and an oral glucose challenge in humans. Clin. Endocrinol. (Oxf.) 81, 841-846.

Tang, W., Lu,Y., Tian, Q.Y., Zhang,Y., Guo, F. J., Liu, G.Y., Syed, N. M., Lai, Y., Lin, E. A., Kong, L., Su, J., Yin, F., Ding, A. H., Zanin-Zhorov, A., Dustin, M. L., Tao, J., Craft, J., Yin, Z., Feng, J. Q., Abramson, S. B., Yu, X. P., Liu, C. J. (2011) The growth factor progranulin binds to TNF receptors and is therapeutic against inflammatory arthritis in mice. Science 332, 478-484.

Tombran-Tink, J., Chader, G. G., Johnson, L.V. (1991) PEDF: a pigment epithelium-derived factor with potent neuronal differentiative activity. Exp. Eye Res. 53, 411-414. 
Trayhurn, P., Beattie, J. H. (2001) Physiological role of adipose tissue: white adipose tissue as an endocrine and secretory organ. Proc. Nutr. Soc. 60, 329-339.

Tsuji, S., Uehori, J., Matsumoto, M., Suzuki, Y., Matsuhisa, A., Toyoshima, K., Seya, T. (2001) Human intelectin is a novel soluble lectin that recognizes galactofuranose in carbohydrate chains of bacterial cell wall. J. Biol. Chem. 276, 23456-23463.

Vázquez-Vela, M. E., Torres, N., Tovar, A. R. (2008) White adipose tissue as endocrine organ and its role in obesity. Arch. Med. Res. 39, 715-728.

Verma, S., Li, S. H., Wang, C. H., Fedak, P.W., Li, R. K., Weisel, R. D., Mickle, D. A. (2003) Resistin promotes endothelial cell activation: further evidence of adipokine-endothelial interaction. Circulation 108, 736-740.

Vieira-Potter, V. J. (2014) Inflammation and macrophage modulation in adipose tissues. Cell. Microbiol. 16, 1484-1492.

Waki, H., Yamauchi, T., Kamon, J., Ito, Y., Uchida, S., Kita, S., Hara, K., Hada, Y., Vasseur, F., Froguel, P., Kimura, S., Nagai, R., Kadowaki, T. (2003) Impaired multimerization of human adiponectin mutants associated with diabetes. Molecular structure and multimer formation of adiponectin. J. Biol. Chem. 278, 40352-40363.

Wang, M.Y., Chen, L., Clark, G. O., Lee,Y., Stevens, R. D., Ilkayeva, O. R., Wenner, B. R., Bain, J. R., Charron, M. J., Newgard, C. B., Unger, R. H. (2010) Leptin therapy in insulin-deficient type I diabetes. Proc. Natl. Acad. Sci. U. S. A. 107, 4813-4819.

Wei, Z., Peterson, J. M., Lei, X., Cebotaru, L., Wolfgang, M. J., Baldeviano, G. C., Wong, G.W. (2012) C1q/TNFrelated protein-12 (CTRP12), a novel adipokine that improves insulin sensitivity and glycemic control in mouse models of obesity and diabetes. J. Biol. Chem. 287, 10301-10315.

Weisberg, S. P., McCann, D., Desai, M., Rosenbaum, M., Leibel, R. L., Ferrante, A.W. Jr. (2003) Obesity is associated with macrophage accumulation in adipose tissue. J. Clin. Invest. 112, 1796-1808.

Welt, C. K., Chan, J. L., Bullen, J., Murphy, R., Smith, P., DePaoli, A. M., Karalis, A., Mantzoros, C. S. (2004) Recombinant human leptin in women with hypothalamic amenorrhea. N. Engl. J. Med. 351, 987-997.

Weyer, C., Funahashi, T., Tanaka, S., Hotta, K., Matsuzawa, Y., Pratley, R. E., Tataranni, P. A. (2001) Hypoadiponectinemia in obesity and type 2 diabetes: close association with insulin resistance and hyperinsulinemia. J. Clin. Endocrinol. Metab. 86, 1930-1935.

Wozniak, S. E., Gee, L. L., Wachtel, M. S., Frezza, E. E. (2009) Adipose tissue: the new endocrine organ? A review article. Dig. Dis. Sci. 54, 1847-1856.

Yamauchi, T., Kamon, J., Waki, H., Terauchi, Y., Kubota, N., Hara, K., Mori, Y., Ide, T., Murakami, K., TsuboyamaKasaoka, N., Ezaki, O., Akanuma, Y., Gavrilova, O., Vinson, C., Reitman, M. L., Kagechika, H., Shudo, K., Yoda, M., Nakano, Y., Tobe, K., Nagai, R., Kimura, S., Tomita, M., Froguel, P., Kadowaki, T. (2001) The fatderived hormone adiponectin reverses insulin resistance associated with both lipoatrophy and obesity. Nat. Med. 7, 941-946.

Yamauchi, T., Kamon, J., Ito, Y., Tsuchida, A., Yokomizo, T., Kita, S., Sugiyama, T., Miyagishi, M., Hara, K., Tsunoda, M., Murakami, K., Ohteki, T., Uchida, S., Takekawa, S., Waki, H., Tsuno, N. H., Shibata, Y., Terauchi, Y., Froguel, P., Tobe, K., Koyasu, S., Taira, K., Kitamura, T., Shimizu, T., Nagai, R., Kadowaki, T. (2003) Cloning of adiponectin receptors that mediate antidiabetic metabolic effects. Nature 423, 762-769.

Yamauchi, T., Kadowaki, T. (2008) Physiological and pathophysiological roles of adiponectin and adiponectin receptors in the integrated regulation of metabolic and cardiovascular diseases. Int. J. Obes. 32, S13-S18 (Suppl. 7).

Yamawaki, H., Tsubaki, N., Mukohda, M., Okada, M., Hara, Y. (2010) Omentin, a novel adipokine, induces vasodilation in rat isolated blood vessels. Biochem. Biophys. Res. Commun. 393, 668-672.

Yamawaki, H., Kuramoto, J., Kameshima, S., Usui, T., Okada, M., Hara, Y. (2011) Omentin, a novel adipocytokine inhibits TNF-induced vascular inflammation in human endothelial cells. Biochem. Biophys. Res. Commun.

408, 339-343.

Smitka K.; Marešová D. 
Yang, R. Z., Lee, M. J., Hu, H., Pray, J., Wu, H. B., Hansen, B. C., Shuldiner, A. R., Fried, S. K., McLenithan, J. C., Gong, D.W. (2006) Identification of omentin as a novel depot-specific adipokine in human adipose tissue: possible role in modulating insulin action. Am. J. Physiol. Endocrinol. Metab. 290, E1253-E1261.

Yang, W. S., Lee, W. J., Funahashi, T., Tanaka, S., Matsuzawa, Y., Chao, C. L., Chen, C. L., Tai, T.Y., Chuang, L. M. (2001) Weight reduction increases plasma levels of an adipose-derived anti-inflammatory protein, adiponectin. J. Clin. Endocrinol. Metab. 86, 3815-3819.

Yannakoulia, M., Yiannakouris, N., Blüher, S., Matalas, A. L., Klimis-Zacas, D., Mantzoros, C. S. (2003) Body fat mass and macronutrient intake in relation to circulating soluble leptin receptor, free leptin index, adiponectin, and resistin concentrations in healthy humans. J. Clin. Endocrinol. Metab. 88, 1730-1736.

Zahorska-Markiewicz, B. (2006) Metabolic effects associated with adipose tissue distribution. Adv. Med. Sci. 51, 111-114.

Zelissen, P. M., Stenlof, K., Lean, M. E., Fogteloo, J., Keulen, E.T., Wilding, J., Finer, N., Rössner, S., Lawrence, E., Fletcher, C., McCamish, M. (2005) Effect of three treatment schedules of recombinant methionyl human leptin on body weight in obese adults: a randomized, placebo-controlled trial. Diabetes Obes. Metab. 7, 755-761.

Zhang, Y., Proenca, R., Maffei, M., Barone, M., Leopold, L., Friedman, J. M. (1994) Positional cloning of the mouse obese gene and its human homologue. Nature 372, 425-432.

Zimmermann, R., Strauss, J. G., Haemmerle, G., Schoiswohl, G., Birner-Gruenberger, R., Riederer, M., Lass, A., Neuberger, G., Eisenhaber, F., Hermetter, A., Zechner, R. (2004) Fat mobilization in adipose tissue is promoted by adipose triglyceride lipase. Science 306, 1383-1386.

Ziora, K.T., Oswiecimska, J. M., Swietochowska, E., Ostrowska, Z., Stojewska, M., Gorczyca, P., Rojewska, K., Ziora-Jakutowicz, K., Szczepanska, M., Ziora, D. (2011a) Assessment of serum levels resistin in girls with anorexia nervosa. Part I. Relationship between resistin and body mass index. Neuro Endocrinol. Lett. 32, 691-696.

Ziora, K.T., Oswiecimska, J. M., Swietochowska, E., Ostrowska, Z., Stojewska, M., Gorczyca, P., Rojewska, K., Ziora-Jakutowicz, K., Szczepanska, M., Ziora, D. (2011b) Assessment of serum levels resistin in girls with anorexia nervosa. Part II. Relationships between serum levels of resistin and thyroid, adrenal and gonadal hormones. Neuro Endocrinol. Lett. 32, 697-703.

Ziora, K., Oświęcimska, J., Swiętochowska, E., Ziora, D., Stojewska, M., Suwała, A., Ostrowska, Z., Gorczyca, P., Klimacka-Nawrot, E., Lukas, W., Błońska-Fajfrowska, B. (2012) Assessment of serum visfatin levels in girls with anorexia nervosa. Clin. Endocrinol. (Oxf.) 76, 514-519. 